\title{
TREATABILITY OF Melia composita USING VACUUM PRESSURE IMPREGNATION
}

\author{
Sadhna Tripathi ${ }^{1, \wedge}$, Pawan Kumar Poonia ${ }^{1}$
}

\begin{abstract}
The performance of treated wood in the field is ultimately affected by retention and penetration of preservative in wood. In the present study, a new preservative system ZiBOC and a commercially used preservative copper-chrome-arsenate (CCA) were used for evaluation of treatability of Melia composita by the vacuum pressure method at different pressure levels in unsealed and end sealed specimens. The retention and penetration levels of both the preservatives were significantly different at $(\mathrm{P}<0.05)$ in sapwood, heartwood and pith zones. Melia composita exhibited treatability class ' $C$ ' $(21-42 \%$ penetration). The results revealed that longitudinal penetration in Melia composita was the dominant flow as examined by spot test for copper in unsealed and end sealed specimens.
\end{abstract}

Keywords: Melia composita, penetration, retention, treatability, ZiBOC.

\section{INTRODUCTION}

The genus Melia consists of fifteen species widely distributed in the warmer parts of Asia and Australia and confined mostly in Indo-Malayan regions. Three species are reported to occur in India i.e. Melia azedarach, Melia birmanica and Melia composita. Anatomically it is difficult to distinguish the three species although gross structural features based on latewood vessels arrangement segregate them into two groups, (i) Melia composita (syn. Melia dubia) (ii) Melia azedarach and Melia birmanica (Sharma et al. 2012).

Melia composita is a fast growing multipurpose tree which can be harvested on short rotation. It is a large tree attaining a height of $20 \mathrm{~m}$ with a spreading crown and a cylindrical straight bole of about 9-10 m. In India, it is mostly distributed in Bengal, Sikkim, Upper Assam, Orissa, Deccan and Western Ghats (Anon 1963, Parthiban et al. 2009). Melia composita trees are generally planted as ornamental trees for shade in plantation and also yield useful timbers. It seasons well if logs are converted in a green state. If left long, the $\log$ is liable to develop end - splitting and discolouration. The wood of $M$. composita can be used for packing cases, cigar boxes, ceiling planks, building and construction materials, agricultural implements, pencils, matchboxes, splints, catamarans, musical instruments, tea boxes, and plyboard (Sharma et al. 2012). It is also a good fuel wood (calorific value, 5,043-5,176 cal). M. composita wood is sold for pulp and used in the veneer industry. However wood composites can be developed with M. composita.

The sapwood is grey or pinkish-white with a yellowish tinge and the heartwood is light red in colour. The wood is moderately hard and $450 \mathrm{~kg} \mathrm{~m}^{-3}$ in weight (Nazma et al. 1981). It is straight grained and coarse textured. The wood is easy to saw, machining satisfactorily and can be finished into a smooth surface. Nazma et al. 1981 reported that the wood is moderately durable under shade whereas it comes in highly perishable group against fungi (Anon 2007).

\footnotetext{
${ }^{1}$ Wood Preservation Discipline, Forest Products Division, Forest Research Institute, Dehradun, India.

^Corresponding Author: tripathis@icfre.org

Received: 22.03.2014 Accepted: 06.08.2014
} 
Wood quality such as microstructure, physical and mechanical properties including processing like sawing, seasoning and preservation are pre-requisite for efficient utilization of any timber species. Presently, the plywood and panel industry is facing acute shortage of raw material and a number of alternate fast growing tree species have been identified for the production of wood based panel products.

Parthiban et al. (2009) have integrated Melia composita in agro-forestry farms as an alternate pulpwood species. A few studies on anatomy of wood, physical and mechanical properties, working qualities including its suitability for plywood, paper and pulp of different species of Melia have been carried out (Agarwal and Pande 1992, Nair and Chavan 1985). The species is newly known to the researcher and public only during the last decade and is now catching up among the plywood industrialist and farmers leading to establishment of plantations. Preliminary evaluations of variations in anatomical properties of Melia composita wood reported that there is a variation in pith to periphery in anatomical features like fiber length, fiber diameter, lumen diameter and double wall thickness (Swaminathan et al. 2012), which may influence the permeability of preservatives in its wood. Reports revealed that in slow grown timber middle portion of wood had higher values for the fiber length, fiber diameter, lumen diameter, double wall thickness of fiber while in fast grown timber outer region had higher values, which may cause differences in permeability of preservative.

Durability in exterior conditions of Melia composita is not reported. For field performance of any nondurable wood, treatment possibilities and it's evaluation in different wood portions is necessary. Studies on different preservative systems which are retained at different levels and show difference in depths of impregnation of various constituents of preservative in wood may help partially to explain results of field performance tests. Keeping in view the wide variability in treatability in plantation species a new method of demarcation of sap, heart and pith was developed (Tripathi 2012). It is essential to evaluate treatability pattern of various portions of log i.e. sap, heart and pith of plantation timber to ensure judicious utilization of timber irrespective of the part of the log. Hence, work on processing and value addition for long term performance is required.

\section{MATERIALS AND METHODS}

\section{Preparation of Wood Specimens}

Harvesting of logs (Melia composita) was done from Forest Research Institute, Dehradun (latitude: $30^{\circ} 19 \mathrm{~N}$ and longitude: $\left.78^{\circ} 04 \mathrm{E}\right)$. Six logs of freshly harvested tree (10-15 feet long) were demarcated as sap, heart and pith portion, on visual basis, at the cut end of logs (Figure 1A and 1B).

Planks of 2.5 inches thickness with full log width and length were converted and seasoned. Seasoned wood was converted into battens of $3.8 \mathrm{~cm}$ (Width) $\times 3.8 \mathrm{~cm}$ (Thickness) and full length. These battens were further processed into specimens of size $3.8 \mathrm{~cm}$ (Width) $\times 3.8 \mathrm{~cm}$ (Thickness) $\times 30.5 \mathrm{~cm}$ (Length). Specimens from pith, heartwood and sapwood were marked as 'P', ' $\mathrm{H}$ ' and 'S' respectively and grouped separately for treatment. Straight grained and defect free specimens were conditioned at $21{ }^{\circ} \mathrm{C}$ and $65 \%$ relative humidity to equilibrate at $12 \%$ moisture content. Before vacuum/pressure treatment, specimens were further divided into two sets. One set of specimens were end sealed with an elastomeric sealant so that penetration and retention values would indicate radial and/or tangential pathways while other set of specimens were taken without end sealed condition to give an indications of absorption/penetration of preservative from all directions (Tripathi 2012). 


\section{Treatment}

Specimens were taken from pith, heartwood and sapwood for treatment at different pressure levels, details of which are given below:

Preservative: $\mathrm{CCA}\left(\mathrm{As}_{2} \mathrm{O}_{5} \cdot 2 \mathrm{H}_{2} \mathrm{O}: \mathrm{CuSO}_{4} \cdot 5 \mathrm{H}_{2} \mathrm{O}: \mathrm{K}_{2} \mathrm{Cr}_{2} \mathrm{O}_{7}\right)$ and $\mathrm{ZiBOC}\left(\mathrm{ZnCl}_{2}: \mathrm{Na}_{2} \mathrm{~B}_{4} \mathrm{O}_{7} \cdot 10 \mathrm{H}_{2} \mathrm{O}: \mathrm{CuSO}_{4} \cdot 5 \mathrm{H}_{2} \mathrm{O}\right)$ Replicates: six in each set of condition and treatment.

No. of specimens

(a) Impregnation of preservative by nine different methods (T-1 to T-9), total 324 specimens were taken.

(b) Treatability evaluations by T- 9 method, total 72 specimens were selected.

\section{Preservative Formulation}

The water soluble preservative copper-chrome-arsenate at 4\% concentration (IS 401:2001) and ZiBOC at $4 \%$ concentration, initially water insoluble but made water soluble with the help of a co-solvent (Tripathi 2008) were used for treatment.

\section{Impregnation of Preservative in Wood}

The treatment was done by full cell method of impregnation (IS 401:2001) using different pressure schedules. The pre-weighed specimens were treated in a pressure cylinder and T-1 to T-9 methods were used to achieve optimum retention and penetration. The details of the 9 treatments are as follows:

T-1: An initial vacuum of $75 \mathrm{kPa}\left(25 \mathrm{in} \mathrm{Hg}\right.$ ) for $30 \mathrm{~min}$ was followed by pressure $689.47 \mathrm{kPa}\left(100 \mathrm{lbs} / \mathrm{in}^{2}\right)$ for $1 \mathrm{~h}$. A Final vacuum of $75 \mathrm{kPa}(25 \mathrm{in} \mathrm{Hg}$ ) for 15 min was applied.

T-2: An initial vacuum of $75 \mathrm{kPa}(25 \mathrm{in} \mathrm{Hg})$ for $30 \mathrm{~min}$ was followed by pressure of $517.11 \mathrm{kPa}\left(75 \mathrm{lbs} / \mathrm{in}^{2}\right)$ for $2 \mathrm{~h}$.

T-3: An initial vacuum of $75 \mathrm{kPa}\left(25 \mathrm{in} \mathrm{Hg}\right.$ ) for 30 min was followed by pressure of $689.47 \mathrm{kPa}\left(100 \mathrm{lbs} / \mathrm{in}^{2}\right)$ for $1 \mathrm{hr}$, specimens were left overnight in preservative solution and then pressure of $517.11 \mathrm{kPa}\left(75 \mathrm{lbs} / \mathrm{in}^{2}\right)$ was applied for $2 \mathrm{~h}$.

T-4: An initial vacuum of $75 \mathrm{kPa}\left(25 \mathrm{in} \mathrm{Hg}\right.$ ) for $30 \mathrm{~min}$ was followed by pressure of $517.11 \mathrm{kPa}\left(75 \mathrm{lbs} / \mathrm{in}^{2}\right)$ for $2 \mathrm{hr}$ and specimens were left overnight in preservative solution.

T-5: An initial vacuum of $75 \mathrm{kPa}(25 \mathrm{in} \mathrm{Hg}$ ) for 30 min was followed by pressure of $1034.21 \mathrm{kPa}(150 \mathrm{lbs} /$ $\left.i^{2}\right)$ for $1 \mathrm{~h}$.

T-6: An initial vacuum of $75 \mathrm{kPa}\left(25 \mathrm{in} \mathrm{Hg}\right.$ ) for 30 min was followed by pressure of $1034.21 \mathrm{kPa}\left(150 \mathrm{lbs} / \mathrm{in}^{2}\right)$ for $1 \mathrm{~h}$ and samples were left overnight in preservative solution.

T-7: A double pressure method was tested for impregnation. An initial vacuum of $75 \mathrm{kPa}(25 \mathrm{in} \mathrm{Hg}$ ) for 30 min was followed by pressure of $689.47 \mathrm{kPa}\left(100 \mathrm{lbs} / \mathrm{in}^{2}\right)$ for $1 \mathrm{~h}$ and $517.11 \mathrm{kPa}\left(75 \mathrm{lbs} / \mathrm{in}^{2}\right)$ for $2 \mathrm{~h}$ and left overnight in preservative solution.

T-8: Specimens were initially autoclaved at $103.42 \mathrm{kPa}\left(15 \mathrm{lbs}\right.$ and $\left.121^{\circ} \mathrm{C}\right)$ in an autoclave (Obromax ${ }^{\mathrm{TM}}$ laboratory autoclave) for $30 \mathrm{~min}$. Specimens were removed and subjected to full cell method of preservative treatment in a treatment plant. An initial vacuum of $75 \mathrm{kPa}(25 \mathrm{in} \mathrm{Hg}$ ) for 30 min was created in plant followed by pressure of $689.47 \mathrm{kPa}\left(100 \mathrm{lbs} / \mathrm{in}^{2}\right)$ for $1 \mathrm{~h}$.

T-9: The specimens were initially steeped in water at $90^{\circ} \mathrm{C}$ for $2 \mathrm{~h}$, removed and placed in a treatment plant and an initial vacuum of $75 \mathrm{kPa}(25 \mathrm{in} \mathrm{Hg}$ ) for 30 min was created and followed by pressure of $1034.21 \mathrm{kPa}$ (150lbs/ in $\left.{ }^{2}\right)$ for $1 \mathrm{~h}$. 
After each treatment, excess preservative was blotted out with filter paper and specimens were weighed immediately to determine the preservative uptake and retention (IS 401:2001). Treated specimens were allowed to dry for 21 days for proper distribution and fixation of preservative and conditioning of specimens. The amount of preservative solution absorbed by specimens (retention value $\mathrm{R}$ in $\mathrm{kg} \mathrm{m}^{-3}$ ) was calculated (Tripathi 2012). Penetration was measured as given below.

\section{Measurement of Penetration}

The penetration of the preservative in each sample; $3.8 \mathrm{~cm}(\mathrm{~W}) \times 3.8 \mathrm{~cm}(\mathrm{~T}) \times 30.5 \mathrm{~cm}(\mathrm{~L})$ was determined by cross cutting the sample in the middle to expose a fresh cross section. The exposed surfaces were then sprayed with Chrome Azurol S solution to indicate the presence of copper. The wood turned blue where the $\mathrm{CCA}$ and $\mathrm{ZiBOC}$ had penetrated, whereas the untreated zones were coloured red. The area of the treated zone and its percentage on total cross section was calculated visually by measuring penetration of preservative in each specimen. All four measurements were averaged to obtain a single penetration value. The penetration data was analyzed as per IS 401:2001, where different treatability classes are defined on the depth of impregnation and total area covered by colour developed for copper:

Class a: Very permeable; impregnated cross-cut area (ICCA): $65-100 \%$; $(3.8 \times 3.8 \mathrm{~cm}$ cross-section)

Class b: Permeable; ICCA: $65-47 \%$

Class c: Moderately permeable; ICCA: $42-21 \%$

Class d: Very resistant; ICCA: $15-10 \%$

Class e: Impermeable; ICCA: nil

The above stated classification is based on the criteria of preservative impregnated cross-cut area of timbers. Whenever the treatment data did not comprehend with the above classification criteria, classification was made to the nearest class. The same scale was applied for sapwood also to see the variability in treatment. On the basis of penetration and retention of preservative in specimens resulted from different treatments, T-9 schedule was selected for treatability evaluation of Melia composita. The statistical analysis was done using analysis of variance (ANOVA) by SPSS 15.0 version. Duncan's homogeneity test was carried out to test the significance and mean separation of the treatments.

\section{RESULTS AND DISCUSSION}

It was observed that cracks and splitting developed in logs, just after felling. It may be due to growth stresses and/ or faulty logging (Figure 1). As Melia composita is fast grown timber growth stresses may be the cause of splitting of logs. The observations is in agreement with Malan (1979) who reported that compressive longitudinal growth stresses tend to increase towards the pith during felling and crosscutting due to which the internal-stress balance is altered resulting in splits and heart checks in the log ends. Growth stresses are more critical in smaller logs from young fast growing trees because of steeper growth stress gradients (Boyd 1950, Hillis 1997). In addition, growth stress release in hardwoods is of much greater magnitude than in softwoods (Archer 1986, Kubler 1987). 


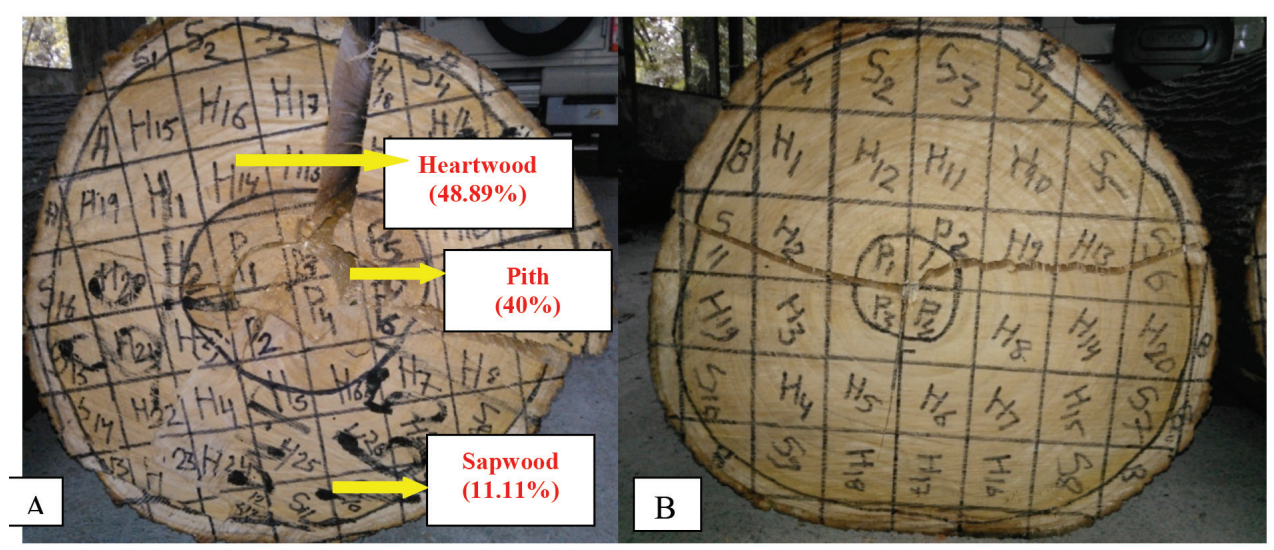

Figure 1. (A-B) Cross-section of log marked to demarcate sapwood (S), heartwood $(\mathrm{H})$ and pith portion $(\mathrm{P})$.

Impregnation of preservative in wood was evaluated by different methods as described in the earlier section. The nine treatments (T-1 to T-9) were tested for optimum retentions and penetrations of both the preservatives in different sections of logs. A significant difference in retention was observed at different pressure levels as shown in table 1. Overall, data showed that maximum mean retention i.e. $14.20 \mathrm{~kg} \mathrm{~m}^{-3} \mathrm{was}$ observed in specimens which were initially boiled (T-9) before pressure treatments. Retention of preservatives was significantly different from each other at 5\% significance level, i.e. ZiBOC exhibited a mean retention of $12.34 \mathrm{~kg} \mathrm{~m}^{-3}$, while CCA exhibited only $11.65 \mathrm{~kg} \mathrm{~m}^{-3}$ for all treatment tested in the study. Maximum retention was found in T-9=14.20 followed by T-3 $=13.24 \mathrm{~kg} \mathrm{~m}^{-3}$. In case of different wood portions mean retention was highest in the pith $\left(25 \mathrm{~kg} \mathrm{~m}^{-3}\right)$ followed by sapwood $\left(5.58 \mathrm{~kg} \mathrm{~m}^{-3}\right)$ and heartwood $\left(5.41 \mathrm{~kg} \mathrm{~m}^{-3}\right)$ and all were significantly different from each other $(\mathrm{P}<0.05)$. Results of Table 1 and 2 showed that treatment $(\mathrm{T}-9)$ exhibited greater depth of impregnation $(80.83 \%)$ and retention $\left(14.20 \mathrm{~kg} \mathrm{~m}^{-3}\right)$. This may be due to more surface absorption of preservative as retentions were calculated on wet weight basis only. Statistically, ZiBOC exhibited a greater depth of impregnation, i.e. $69.19 \%$ compared with that of CCA $(67.12 \%)$ in different set of experiments. 
Table 1. Mean retention of preservatives in different wood portions by different methods of treatment.

\begin{tabular}{|c|c|c|c|c|c|c|c|}
\hline \multirow{2}{*}{ Treatment } & \multirow{2}{*}{ Method } & \multicolumn{3}{|c|}{ Retention of CCA $\left(\mathrm{kgm}^{-3}\right)$} & \multicolumn{3}{|c|}{ Retention of $\mathrm{ZiBOC}\left(\mathrm{kgm}^{-3}\right)$} \\
\hline & & Pith & Heartwood & Sapwood & Pith & Heartwood & Sapwood \\
\hline $\mathrm{T}-1$ & $100 \mathrm{lbs} / 1 \mathrm{~h}$ & 18.77 & 5.49 & 5.08 & 24.52 & 5.36 & 4.22 \\
\hline $\mathrm{T}-2$ & $75 \mathrm{lbs} / 2 \mathrm{~h}$ & 25.56 & 5.25 & 3.63 & 25.7 & 5.3 & 4.22 \\
\hline $\mathrm{T}-3$ & $\begin{array}{l}100 \mathrm{lbs} / 1 \mathrm{~h} \text {, left overnight and } \\
\text { then } 75 \mathrm{lbs} / 2 \mathrm{~h}\end{array}$ & 27.02 & 5.53 & 6.5 & 27.92 & 7.5 & 6.3 \\
\hline T-4 & 75lbs/2h \& overnight dipping & 24.38 & 5.76 & 5.81 & 25.68 & 4.67 & 4.40 \\
\hline T-5 & $150 \mathrm{lbs} / 1 \mathrm{~h}$ & 20.70 & 4.75 & 7.5 & 22.17 & 5.22 & 5.63 \\
\hline T-6 & 150lbs/1h \& overnight dipping & 18.43 & 4.49 & 5.67 & 21.35 & 5.35 & 6.13 \\
\hline $\mathrm{T}-7$ & $\begin{array}{l}100 \mathrm{lbs} / 1 \mathrm{~h} \text {, left overnight then } \\
75 \mathrm{lbs} / 2 \mathrm{~h} \text { and then overnight } \\
\text { dipping }\end{array}$ & 27.92 & 3.03 & 3.79 & 26.92 & 7.5 & 6.5 \\
\hline $\mathrm{T}-8$ & $\begin{array}{l}\text { Autoclaved at } 15 \mathrm{lbs} \text { and } 121^{\circ} \mathrm{C} \\
\text { then treated at } 100 \mathrm{lbs} / 1 \mathrm{~h}\end{array}$ & 27.65 & 5.22 & 5.23 & 27.92 & 5 & 6.02 \\
\hline T-9 & $\begin{array}{l}\text { Initial boiled at } 90^{\circ} \mathrm{C} / 2 \mathrm{~h} \text {, then } \\
\text { treated at } 150 \mathrm{lbs} / 1 \mathrm{~h}\end{array}$ & 28.96 & 6.08 & 7.25 & 29.95 & 6.35 & 6.63 \\
\hline $\begin{array}{l}\text { Mean } \\
\text { condition }\end{array}$ & $\begin{array}{l}\mathrm{T}-1=10.54^{\mathrm{a}}, \mathrm{T}-2=11.66^{\mathrm{b}}, \mathrm{T}-3= \\
9=14.20^{\mathrm{i}}\end{array}$ & $3.24^{\mathrm{c}}, \mathrm{T}$ & $=11.78^{\mathrm{d}}, \mathrm{T}$ & $10.99^{\circ}, \mathrm{T}-6$ & $10.23^{f}$, & $7=12.49^{\mathrm{g}}, \mathrm{T}$ & $=12.84^{\mathrm{h}}, \mathrm{T}-$ \\
\hline $\begin{array}{l}\text { Mean wood } \\
\text { portion }\end{array}$ & $\mathrm{P}-25^{\mathrm{j}}, \mathrm{S}-5.58^{\mathrm{k}}, \mathrm{H}-5.41^{1}$ & & & & & & \\
\hline $\begin{array}{l}\text { Mean } \\
\text { preservative }\end{array}$ & $\mathrm{CCA}-11.65^{\mathrm{m}}, \mathrm{ZiBOC}-12.34^{\mathrm{n}}$ & & & & & & \\
\hline
\end{tabular}

$\mathrm{CD}_{(0.05)}$ treatment $=0.12$, preservative $=0.05$, wood portion $=0.07$. Different letters denote significantly different groups.

Penetration of preservatives in different sections of wood is shown in figure 2. Impregnation of preservative was evaluated by color test of copper on the cut cross- section of specimens and the mean of all the four sides was taken. Maximum penetration i.e. $83.75 \%$ was observed in double pressure treatment (T-3) followed by T-9 $(80.83 \%)$ and T-7 (80.83\%). In case of different wood portions the highest mean penetration was found in pith $(92.25 \%)$ followed by sapwood $(67.55 \%)$ and heartwood $(40.42 \%)$ by different methods of treatment (Table 2). It was observed that pith is easily treatable as compared to sap and heartwood. Sap and heartwood both exhibited resistance against treatment; this may be due to the presence of round or oval outlined vessels often filled with colored gummy deposits in it, which do not allow proper absorption of preservative during treatment (Agarwal and Pande 1992). It is assumed that the gummy deposits are water soluble which provides space for treatment during initial heating in T-9 method and this may be helpful to increase treatability. The results of penetration and retention of preservative are in accordance with the established results of other workers (British Wood Preserving Association 1956). Treatability difference was observed from pith to periphery. In heartwood, extractives can infiltrate completely into the cell walls or they may occur as surface deposits or plugs in cell lumina. Their presence in wood affects the permeability and physical properties of wood (Hunt and Garratt 1967). Literature on extractives in Melia composita is not reported. 
Table 2. Mean percentage penetration of preservatives in different wood portions by different methods of treatment.

\begin{tabular}{|c|c|c|c|c|c|c|c|}
\hline \multirow{2}{*}{ Treatment No. } & \multirow{2}{*}{ Method } & \multicolumn{3}{|c|}{ Penetration of CCA $4 \%$} & \multicolumn{3}{|c|}{ Penetration of ZiBOC $4 \%$} \\
\hline & & Pith & Heartwood & Sapwood & Pith & Heartwood & Sapwood \\
\hline T-1 & $100 \mathrm{lbs} / 1 \mathrm{~h}$ & 50 & 5 & 10 & 90 & 15 & 15 \\
\hline $\mathrm{T}-2$ & $75 \mathrm{lbs} / 2 \mathrm{~h}$ & 100 & 25 & 80 & 100 & 25 & 80 \\
\hline $\mathrm{T}-3$ & $\begin{array}{c}100 \mathrm{lbs} / 1 \mathrm{~h}, \text { left } \\
\text { overnight and then } \\
75 \mathrm{lbs} / 2 \mathrm{~h}\end{array}$ & 100 & 45 & 100 & 100 & 75 & 90 \\
\hline $\mathrm{T}-4$ & $\begin{array}{l}\text { 75lbs/2h \& overnight } \\
\text { dipping }\end{array}$ & 100 & 70 & 10 & 100 & 55 & 60 \\
\hline $\mathrm{T}-5$ & $150 \mathrm{lbs} / 1 \mathrm{~h}$ & 100 & 15 & 70 & 100 & 45 & 50 \\
\hline T-6 & $\begin{array}{l}\text { 150lbs/1h \& overnight } \\
\text { dipping }\end{array}$ & 100 & 25 & 70 & 100 & 30 & 80 \\
\hline $\mathrm{T}-7$ & $\begin{array}{c}100 \mathrm{lbs} / 1 \mathrm{~h}, \text { left } \\
\text { overnight then } \\
75 \mathrm{lbs} / 2 \mathrm{~h} \text {, and then } \\
\text { overnight dipping }\end{array}$ & 100 & 45 & 100 & 100 & 70 & 70 \\
\hline $\mathrm{T}-8$ & $\begin{array}{c}\text { Autoclaved at } 15 \mathrm{lbs} \\
\text { and } 121^{\circ} \mathrm{C} \text { then treated } \\
\text { at } 100 \mathrm{lbs} / 1 \mathrm{~h}\end{array}$ & 100 & 65 & 90 & 100 & 35 & 50 \\
\hline T-9 & $\begin{array}{c}\text { Initial boiled at } 90^{\circ} \mathrm{C} \\
/ 2 \mathrm{~h} \text { then treated at } \\
150 \mathrm{lbs} / 1 \mathrm{~h}\end{array}$ & 100 & 50 & 100 & 100 & 45 & 100 \\
\hline $\begin{array}{l}\text { Mean } \\
\text { condition }\end{array}$ & \multicolumn{7}{|c|}{$\begin{array}{l}\mathrm{T}-1=30.41^{\mathrm{a}}, \mathrm{T}-2=67.63^{\mathrm{b}}, \mathrm{T}-3=83.75^{\mathrm{c}}, \mathrm{T}-4=65.83^{\mathrm{d}}, \mathrm{T}-5=63.33^{\mathrm{e}}, \mathrm{T}-6=67.5^{\mathrm{b}}, \mathrm{T}-7=80.83^{\mathrm{f}}, \mathrm{T}-8=73.33^{\mathrm{g}}, \\
\mathrm{T}-9=80.83^{\mathrm{f}}\end{array}$} \\
\hline $\begin{array}{l}\text { Mean wood } \\
\text { portion }\end{array}$ & \multicolumn{7}{|c|}{$\mathrm{P}-92.25^{\mathrm{g}}, \mathrm{S}-67.55^{\mathrm{hr}}, \mathrm{H}-40.42^{\mathrm{i}}$} \\
\hline $\begin{array}{l}\text { Mean } \\
\text { preservative }\end{array}$ & \multicolumn{7}{|c|}{ CCA-67.12 $2^{\mathrm{j}}, \mathrm{ZiBOC}-69.19^{\mathrm{k}}$} \\
\hline
\end{tabular}

$\mathrm{CD}_{(0.05)}$ treatment $=0.32$, preservative $=0.15$, wood portion $=0.18$. Different letters denote significantly different groups. 


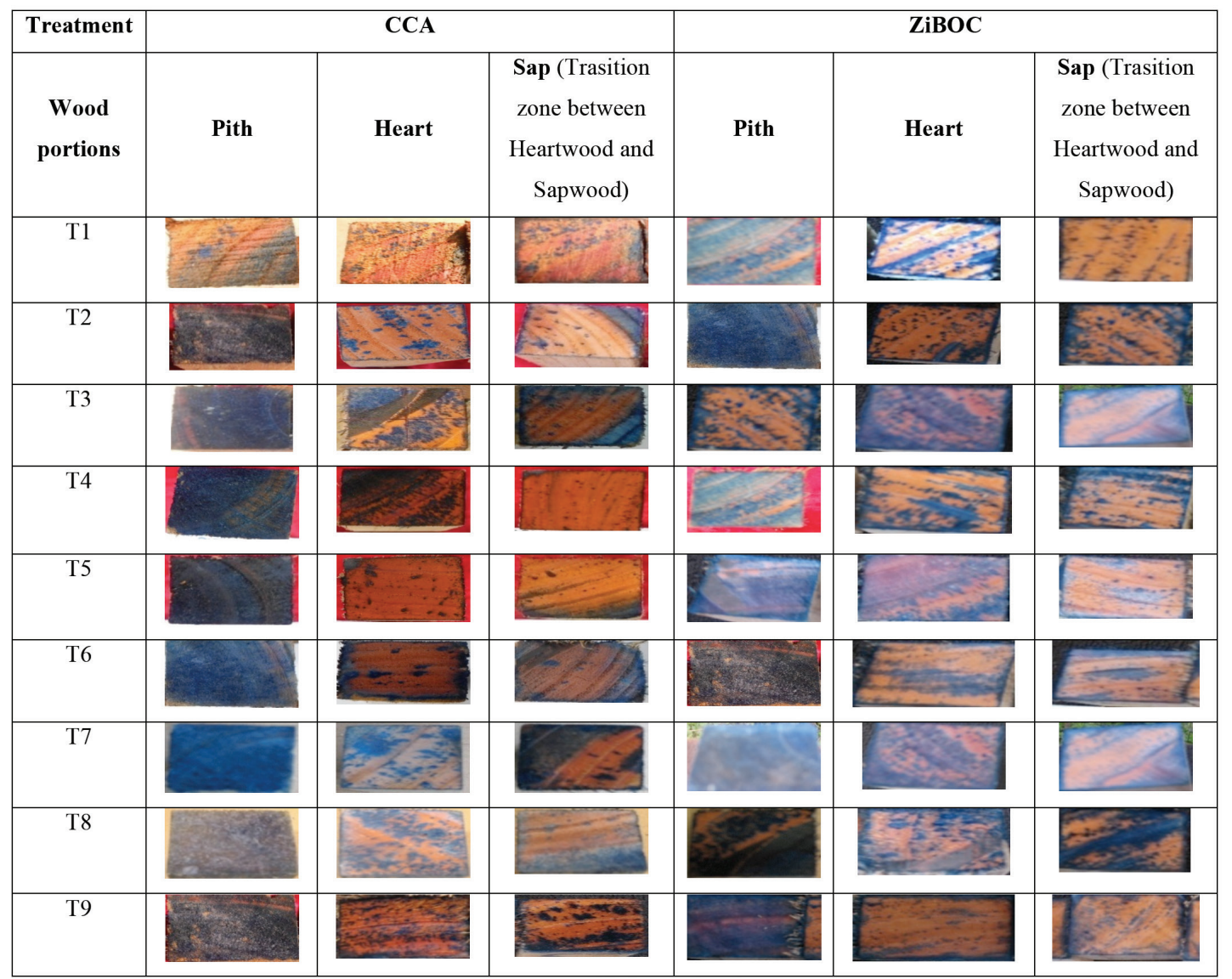

Figure 2. Treatments T-1 to T-9 exhibiting depth of preservatives (CCA and ZiBOC) impregnation in different sections of wood examined by spot test.

Treatability evaluation was done by T-9 method. Retention of ZiBOC and CCA in Melia composita in different wood portions at different pressure levels in unsealed and end sealed conditions are shown in table 3. Unsealed specimens exhibited higher values for mean retentions $\left(14.11 \mathrm{~kg} \mathrm{~m}^{-3}\right)$ as compared to end sealed $\left(12.76 \mathrm{~kg} \mathrm{~m}^{-3}\right)$ in heartwood portion. This was expected since application of sealant at the end allows penetration only from the transverse direction. It is clearly revealed that mean values of retentions were found maximum in pith $\left(27.69 \mathrm{~kg} \mathrm{~m}^{-3}\right)$ followed by sapwood $\left(6.67 \mathrm{~kg} \mathrm{~m}^{-3}\right)$, irrespective of the two preservatives. Retention of preservatives was significantly different from each other at $5 \%$ significance level. Results revealed that the $\mathrm{ZiBOC}$ showed higher retention and penetration compared to CCA in end sealed and unsealed specimens (Table 3 and 4) 
Table 3. Mean retention (T-9) of preservatives in Melia composita in different wood portions.

\begin{tabular}{|l|c|c|c|c|c|c|}
\hline \multirow{2}{*}{ Condition } & \multicolumn{4}{|c|}{ Retention of CCA $\left(\mathrm{kgm}^{-3}\right)$} & \multicolumn{3}{c|}{ Retention of ZiBOC $\left(\mathrm{kgm}^{-3}\right)$} \\
\cline { 2 - 7 } & Pith & heartwood & sapwood & Pith & heartwood & sapwood \\
\hline End sealed(EN) & 26.15 & 5.59 & 5.60 & 27.87 & 5.72 & 5.94 \\
\hline \multicolumn{1}{|l|}{ Unsealed(UN) } & 28.96 & 6.08 & 7.25 & 29.95 & 6.48 & 7.34 \\
\hline $\begin{array}{l}\text { Mean (conditions) } \\
\text { (wood }\end{array}$ & $\mathrm{UN}=14.11^{\mathbf{a}}, \mathrm{EN}=12.76^{\mathbf{b}}$ \\
\hline $\begin{array}{l}\text { Mean } \\
\text { portions) }\end{array}$ & $\mathrm{P}=69^{\mathbf{c}}, \mathrm{S}=6.67^{\mathbf{d}}, \mathrm{H}=5.94^{\mathbf{e}}$ \\
\hline $\begin{array}{l}\text { Mean } \\
\text { (preservatives) }\end{array}$ & $\mathrm{CCA}=12.94^{\mathbf{f}}, \mathrm{ZiBOC}=13.92^{\mathrm{g}}$ \\
\hline
\end{tabular}

Table 4. Mean percentage penetration (T-9) of preservatives in Melia composita in different wood portions.

\begin{tabular}{|c|c|c|c|c|c|c|}
\hline \multirow{2}{*}{\begin{tabular}{c} 
Condition \\
\cline { 2 - 7 }
\end{tabular}} & \multicolumn{3}{|c|}{ Penetration of CCA 4\% } & \multicolumn{3}{|c|}{ Penetration of ZiBOC 4\% } \\
\cline { 2 - 6 } & Pith & heartwood & sapwood & Pith & heartwood & sapwood \\
\hline End sealed(EN) & 100 & 25 & 85 & 100 & 30 & 100 \\
\hline Unsealed(UN) & 100 & 40 & 100 & 100 & 45 & 100 \\
\hline $\begin{array}{c}\text { Mean } \\
\text { (conditions) }\end{array}$ & $\mathrm{UN}=78.19^{\mathbf{a}}, \mathrm{EN}=73.61^{\mathbf{b}}$ \\
\hline $\begin{array}{c}\text { Mean } \\
\text { (wood portions) }\end{array}$ & $\mathrm{P}=100^{\mathbf{c}}, \mathrm{S}=93.33^{\mathbf{d}}, \mathrm{H}=34.37^{\mathbf{e}}$ \\
\hline $\begin{array}{c}\text { Mean } \\
\text { (preservatives) }\end{array}$ & $\mathrm{CCA}=75^{\mathbf{f}}, \mathrm{ZiBOC}=76.8^{\mathbf{g}}$ \\
\hline
\end{tabular}

Figure 3 shows impregnation of preservative by color test of copper on the cut cross- section of specimens and the average of all the four sides was taken. Six replicates were taken from pith, heart and sapwood in unsealed and end sealed condition at different pressure levels with two preservatives. As per the measurement of penetrability Melia composita fall in treatability class "C" exhibiting $42-21 \%$ average area for impregnation of copper. Unsealed wooden blocks allowed preservative penetration from all the directions. End sealed wooden blocks allowed both tangential and radial penetration. Penetration of copper in end sealed specimens was significantly lower than unsealed specimens with regard to cross-section penetrated irrespective of pressure. This suggests that longitudinal penetration is the dominant flow in Melia composita. In hard wood species without tyloses, penetration in the longitudinal direction is usually greater than in the transverse directions (Tripathi 2012). 


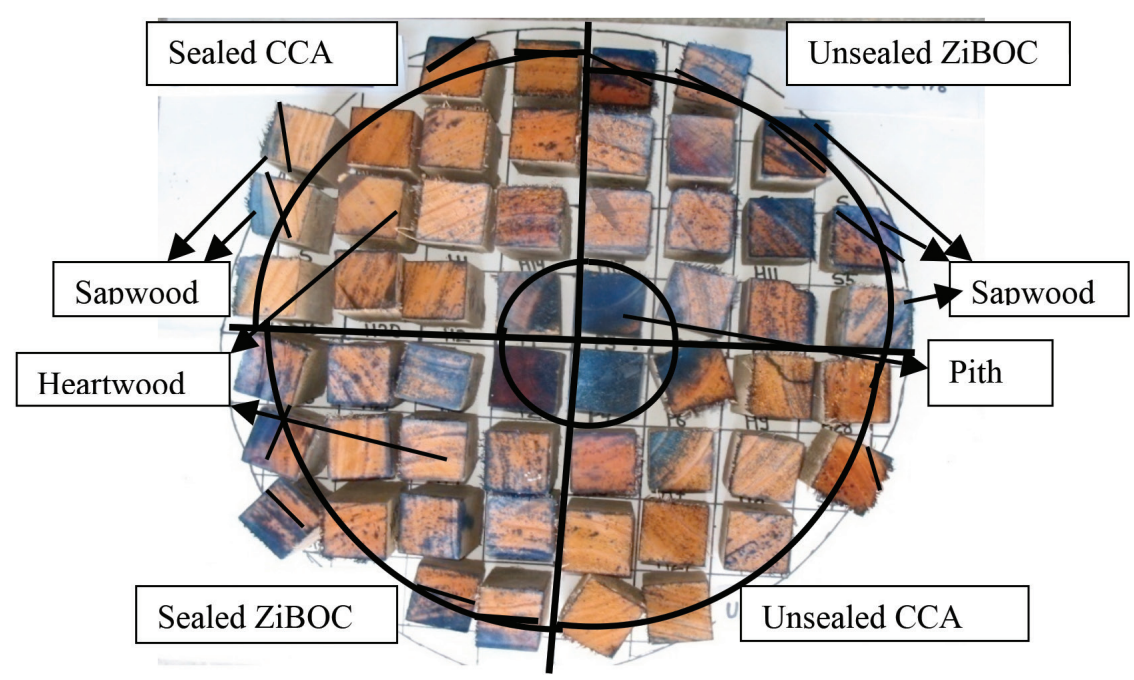

Figure 3. Penetration of preservative CCA and ZiBOC (4\%) in sealed and unsealed specimens for treatability evaluation.

Correlation coefficient " $r$ " was calculated between density and retention of preservative. A negative and significant correlation $(\mathrm{P}<0.01, \mathrm{r}=-0.873)$ was observed between density and retention. The results revealed that higher the density, the lower will be the retention of preservative which is expected also since the void volume decreases with increasing density. However, in the present study, it was observed that pith had the lowest average density $329 \mathrm{~kg} \mathrm{~m}^{-3}$ followed by $387 \mathrm{~kg} \mathrm{~m}^{-3}$ and $450 \mathrm{~kg} \mathrm{~m}^{-3}$ for sapwood and heartwood respectively. Factors like small pore size is one of the reasons for difficulty in treatment of heartwood (Petty and Preston 1969, Stamm 1970), the irreversible nature of pit aspiration in the heartwood (Usta 2005, Thomas and Nicholas 1966, Thomas and Kringstad 1971), the amount and type of extractives deposited on pit membranes during the formation of heartwood (Panshin and DeZeeuw 1980, Cote 1990), in addition, for hardwoods, tyloses formation in the heartwood (Panshin and DeZeeuw 1980, Cote 1990).

\section{CONCLUSIONS}

Melia composita is not studied so far for treatability evaluation. Conversion soon after harvesting is suggested to avoid splits in the logs. Present study was carried out to examine the impregnation of two water based preservatives in different sections i.e. heartwood, sapwood and pith. Melia composita exhibited treatability class " $\mathrm{C}$ ". Hence it is categorized as moderately permeable; ICCA: 42-21\%. Pith exhibited through and through impregnation of preservative while heartwood and sapwood exhibited almost similar retentions and penetrations it may be because of the presence of very small portion of sap wood. T-9 method of treatment was found best among all methods tested. Study suggests that pressure treatment at 1034.21 $\mathrm{kPa}$ after "steeped" in water at $90 \mathrm{oC}$ for $2 \mathrm{~h}$ is the best treatment for this species. Retention and penetration of ZiBOC and CCA preservative varied from pith to periphery. Pressure levels have significantly affected the distribution of copper in different wood portions. It can be concluded that different treatment methods and the density of wood in different wood portions have a significant role in the penetration of preservative. 


\section{ACKNOWLEDGEMENTS}

The authors thank The Director of the Forest Research Institute, Dehradun, India, for providing facilities. The authors are also grateful to the staff of the Wood Preservation Discipline, F.R.I. Dehradun, for providing necessary help during the experimental work.

\section{REFERENCES}

Agarwal, S.P.; Pande, P.K. 1992. Anatomy of commercial timbers of south zone Part II. Indian Forest Records, Wood Anatomy 4(3). ICFRE, Dehradun.

Anon. 1963. Indian woods: their identification properties and uses. Vol. II. The Manager of Publications, Delhi, P. 386.

Anon. 2007. Annual report. Institute of wood science and technology. Banglore. p.121.

Archer, R.R. 1986. Growth stresses and strains in trees. Springer-Verlag, Berlin, 240 pp.

Boyd, J.D. 1950. Tree growth stresses. Part II. The development of shakes and other visual failures in timber. Australian J of Applied Sci 1:296-312.

British Wood Preserving Association. 1956. Timber preservation. London: British Wood Preserving Association.

Bureau of Indian standards. IS. 2001. Preservation of timber-code of practice. IS: 401- 2001. Manak Bhawan, New Delhi, India.

Cote, W.A. 1990. In search of pathway through wood. Proc. Ann. Meet. of American Wood Preserver's Association. Stevensville, MD, USA, April 1990. American Wood Preserver's Association. Vol. 86, 97-105.

Hillis, W.E. 1997. Timber management toward wood quality and end-wood product value: Australia's experience. In: Timber management toward wood quality and end-product value (Zhang, Sy; Grosselin,R.; Chauret, G., editors), Proceedings of the CTIA/IUFRO International Wood Quality Workshop, August 18-22, 1997, Division III. pp 47-53.

Hunt, G.M.; Garratt, G.A. 1967. Wood preservation. $3^{\text {rd }}$ ed. The American forestry Series, New York: McGraw-Hill.

Kubler, H. 1987. Growth stresses in trees and related wood properties. For Abstr 48:131-189.

Malan, F.S. 1979. The control of end splitting in sawlogs: a short literature review. South African For $J$ 109:14-18.

Nair, M.N.B.; Chavan, R.R. 1985. Dimensional analysis of some wood parameters in eleven timber trees. Indian Forester III: 410-417.

Nazma; Ganapathy, P.M.; Sasidharan, N.; Bhat, K.M.; Gnanaharan, R. 1981. A Handbook of Kerala Timbers. KFRI Research Report No: 9: 260p.

Panshin, A.J.; Dezeeuw, C. 1980. Text book of wood technology. New York: McGraw-Hill Book Company. 
Parthiban, K.T.; Bharathi, A.K.; Seenivasan, R.; Kamala, K.; Rao, M.G. 2009. Integrating Melia dubia in agro-forestry farms as an alternate pulpwood species. J APA News 34: 3-4.

Petty, J.A.; Preston, R.D.1969. The dimension and number of pit membrane pores in conifer wood. Proc R Soc Lond B 172: 137-151.

Sharma, S.K.; Shukla, S.R.; Sujatha, M.; Shashikala, S.; Kumar, P. 2012. Assessment of certain wood quality parameters of selected genotypes of Melia dubia cav. Grown in a seedling seed orchard. $J$ Indian Acad Wood Sci 9: 165-169.

Stamm, A.J. 1970. Maximum effective pit pore radii of the heartwood and sapwood of six soft wood as affected by drying and resoking. Wood Fiber 1: 263-269.

Swaminathan, C.; Vijendrarao, R.; Shashikala, S. 2012. Preliminary evaluations of variations in anatomical properties of Melia dubia Cav. wood. International Research Journal of Biological Science 4:1-6.

Thomas, R.J.; Kringstad, P. 1971. The role of hydrogen bonding in pit aspiration. Holzforschung 25:143-149.

Thomas, R.J.; Nicholas, D.D. 1966. Pit membrane structure in loblolly pine influenced by solvent exchange drying. Forest Prod J 16: 57-59.

Tripathi, S. 2008. New eco-friendly, economical and non-hazardous wood preservative ZiBOCcomparable to CCA. Patent Filed 264/Del/2008. India.

Tripathi, S. 2012. Treatability evaluation of meranti with ZiBOC and CCA. International Wood Products Journal 3:70-76.

USTA, I. 2005. A review of the configuration of bordered pits to stimulate the fluid flow. Maderas. Ciencia y tecnología 7(2):121-132. 